IRA-International Journal of Management \&

Social Sciences

ISSN 2455-2267; Vol.10, Issue 01 (January 2018)

Pg. no. 54-62.

Institute of Research Advances

http://research-advances.org/index.php/RAJMSS

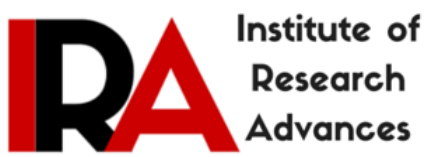

\title{
The Digitization Wave in India: A SWOC Analysis with Special Reference to the Demonetization and a Leap towards Cashless Economy
}

\author{
Prasenjit Roy \\ Ph.D. Research Scholar, Dept. of Commerce, North Eastern Hill University, Shillong-793022, Meghalaya, \\ India.
}

Type of Review: Peer Reviewed.

DOI: http://dx.doi.org/10.21013/jmss.v10.n1.p6

\section{How to cite this paper:}

Roy, P. (2018). The Digitization Wave in India: A SWOC Analysis with Special Reference to the Demonetization and a Leap towards Cashless Economy. IRA-International Journal of Management \& Social Sciences (ISSN 2455-2267), 10(1), 54-62. doi:http://dx.doi.org/10.21013/jmss.v10.n1.p6

\section{(C) Institute of Research Advances.}

\section{(c)) BY-No}

This work is licensed under a Creative Commons Attribution-Non Commercial 4.0 International License subject to proper citation to the publication source of the work.

Disclaimer: The scholarly papers as reviewed and published by the Institute of Research Advances (IRA) are the views and opinions of their respective authors and are not the views or opinions of the IRA. The IRA disclaims of any harm or loss caused due to the published content to any party.

Institute of Research Advances is an institutional publisher member of Publishers Inter Linking Association Inc. (PILA-CrossRef), USA. The institute is an institutional signatory to the Budapest Open Access Initiative, Hungary advocating the open access of scientific and scholarly knowledge. The Institute is a registered content provider under Open Access Initiative Protocol for Metadata Harvesting (OAI-PMH).

The journal is indexed \& included in WorldCat Discovery Service (USA), CrossRef Metadata Search (USA), WorldCat (USA), OCLC (USA), Open J-Gate (India), EZB (Germany) Scilit (Switzerland), Airiti (China), Bielefeld Academic Search Engine (BASE) of Bielefeld University, Germany, PKP Index of Simon Fraser University, Canada. 


\begin{abstract}
The recent demonetisation has pushed up the volume of digital payments and efforts to a cashless economy. According to the World Payment Report 2017, the Government of India has set a target to achieve 25 billion non-cash transactions by 2017-18 commencing a roadmap towards a full-fledged digital economy. Nevertheless, the situation of India with this regard is critical as there are numerous setbacks ranging from socio-economic to geo-political dimensions that has and will have an effect on the digital transition. The changing market scenario and the technological advancements of smartphones and internet have opened up a Pandora's Box. This served as other drivers to the development of digital banking, e-wallets, e-commerce, green banking, mobile banking and so forth. This paper is focused on understanding the prospects and challenges of cashless economy in India. As a corollary to this the paper also tries to identify various loopholes in the system which might hinder the growth of digitisation process in the country. The analysis suggests how digital illiteracy, digital divide, lack of infrastructure, cyber security and so forth affects the transition of a cashless society in a developing country like India. The challenges are immense; however a thorough planning and implementation of policies to tackle them would smoothen out the transition process and work to the benefit of the nation.
\end{abstract}

Keywords: Cashless Economy, Demonetisation, Digital Illiteracy, Digital Divide.

\title{
1.1. Introduction
}

The advent of demonetisation as a means to eliminate setbacks in the economy by the Government of India has also pushed the need of cashless economy and digital payments. This has brought a new wave of change and a paradigm shift in the use of digital platform as a means for monetary transactions. Although the digital payment scene was making rounds since many years, however, it did not get an important impetus among the masses due to the shift in technological habits. A majority of the Indian population lives in rural area where numerous shortcomings never supported the use of digital platforms. Apart from this the adamant attitude of the people for not using digitised channels never helped in bringing out digital modes as one of the primary process for payments. The changing market scenario and the technological advancements of smartphones have opened up a Pandora's Box. This served as other drivers to the development of digital banking, e-wallets, e-commerce, green banking, mobile banking and so forth.

The World Payment Report (2017) indicates that the volume of non-cash transactions has grown by 11.2 percent during 2014-15 reaching 433.1 billion clients. This also signifies the highest growth of the decade. Certain specific regions like Asia, Central Europe, Middle East and Africa recorded a better growth where Asia had 43.4 percent growth. This has lot to do with the changing face of the economy and the move towards digitisation in these countries. The adoption of mobile wallets and other digital channels of payments among the masses of emerging economies in Asia have also increased within a short span of time which reflects to the high growth. The matured markets recorded a growth of 6.8 percent in the volume. The emerging markets throughout the world witnessed a share of 32.1 percent while the matured markets have a share of 67.9 percent. The report acknowledges the demonetisation move by the Government and also forecasts that India is expected to grow at 26.2 percent from 2016-2020 in the volume of non-cash transactions with the necessary support from the agencies of digital payments.

The demonetisation move has pushed up the volume of digital payments and efforts to a cashless economy. The Government of India has set a target to achieve 25 billion non-cash transactions by 2017-18 which will comprise of 11 billion card based transactions, 6 billion mobile based and 8 billion online transactions (World Payment Report, 2017). This has started the formation of a roadmap towards a full-fledged digital economy. Nevertheless, the Indian economy has numerous setbacks ranging from socio-economic to geopolitical dimensions. This has an effect on the sentiments of the people which further shapes the habits in availing services of digitisation. The currency to GDP has decreased from 12 percent during pre-demonetisation to 10.06 percent at the present (World Economic Database Outlook, 2017). India ranks among the top ten cash intensive countries in the world. The transition from cash oriented economy to cashless economy will require extensive planning for an all-round development. More importantly the strategic promptness and adaptability in the economy. This paper focuses on the prospects and challenges of cashless economy in India. As a corollary to this the paper also tries to identify various loopholes in the system which might hinder the growth of digitisation process in the country. The paper is descriptive in nature and applies the SWOC (Strength Weakness Opportunities and Challenges) method for analysis. The remaining sections of the paper are organised as follows; Section 2 presents the literature review, Section 3 deals with the SWOC analysis and lastly Section 4 consists of concluding remarks with suggestions and scope of further research. 


\subsection{Literature Review}

Cashless economy is described as the state of the economy where financial transactions are conducted through digital platforms between the relevant parties. Unlike normal financial transactions where physical banknotes, currency and coins holds a prominent share for exchange, cashless economy is entirely based on other instruments which represents the digital information of money (Chakravorti \& Mazzotta, 2013). The concept of cashless transactions is centuries old where barter system provided a medium of exchange without any physical cash. However, the advent of digital age and technological advancement have brought up the concept of "Cashless Economy" into the forefront which refers entirely to the digital transformation of physical cash where the legal tender of money is documented and exchanged through a digital form (Dhammi et al., 2017). The IoT (Internet of Things) is a network which is used for the interface bridging the gap from the service providers to the end users. It enables the collection and exchange of data across various platforms in digitisation. IoT is big in itself which deals with all the types of data, including financial and economic data.

The rapid expansion of digital services and technological change has pushed the realm of economic transactions to a different platform which made recording and maintenance of information more efficiently with minimum effort. This gave scope to the acceptance of automation and digitisation. The earliest wave of digital transformation can be traced to 1990s when world wide web was catching attention followed by the dot com boom. The first generation consisted of digital payment providers like Paypal, Digital Wallets by Apple. These companies had limited exposure due to which they were not successful in the beginning. The second generation consisted of big names such as MasterCard, Visa and other leading banks and lenders. However, the lack of flexibility in usage did not made them successful. The third-generation digital payments system in the present day works as a charm as they took care of the earlier issues (InformIT Editorial Team, 2004). Today it has become one of the major innovations of the $21^{\text {st }}$ century bringing in uniformity across the globe.

The transition to a cashless economy has its own advantages and disadvantages from numerous dimensions. It is broadly proclaimed to bring in positive development and provide wide range of benefits to all the players in the economy. One of the primary reasons for this is to curb the circulation of cash as major chunk of it is alleged to be static in nature and stacked through unethical means (Khurana, 2017). Further, a cash concentric society is linked with having more illegal practices such as crime, drug peddling, terrorism, illegal immigration, human trafficking, smuggling and corruption (Basir, 2009). A cashless economy signifies a reduction in the volume of cash transaction and at the same time provide a means to curb down tax evasive practices. This also helps to bridge the gap from parallel economy and bring transparency in trade and business (Das and Agarwal, 2010).

The evidences throughout the world show the positive benefits of cashless economy. A study on 51 countries points out that use of electronic card has added USD 1.1 trillion dollars private consumption during 2003 to 2008. This indicates a positive relationship of cashless transactions with consumption and GDP (Moody's Analytics, 2013). Another study on 56 countries indicates similar observations from 2008 to 2012 where USD 983 billion dollars were added to the GDP for increased cashless transactions. The study also points out a bright prospect of digitisation in the emerging markets like India, China, Russia and Brazil (Zandi et al., 2013). A study on European Union from 1995-2009 also indicates a positive relationship of cashless transactions to GDP. More specifically increase penetration of card based payments will boost the GDP by 6 million EURO (Hasan et al., 2013).

An estimated 21,000 crores are spent by the RBI (Reserve Bank of India) for cash management annually. Along with this other effect of cash usage like transactions from unorganised market, black money, parallel economy, tax evasion, illegal practices and so forth are also absorbed by the RBI which requires huge amount of monetary resources (Mazzotta, et al. 2015). It has been duly noted that using cashless means of transactions might save huge sums of money and bank costs over time. A study on banks of Norway and Netherlands from 1990 to 2004 shows that cashless payment instruments save up to 0.35 percent and 0.61 percent of bank costs to GDP of the respective countries (Bolt et al., 2008). An estimation of cost of hourly wage rate of a representative along with the total number of ATM transactions indicated a massive saving for the banks in terms of costs, time and effort (Kruger and Seitz, 2014).

In our present times the technological advancement has created a massive wave of change in the domain of digital payments. The higher dependence on cash due to its convenience have developed a deeprooted habit among the masses. The transformation to cashless means would require higher efficiency, reliability and security in order to create it as an encouraging platform for business (Ernest \&Young 2013). The digital movement will boost the Indian economy substantially which will further contribute positively to the GDP of the country (Kapoor, 2016). Along with this it is also expected to bring other radical changes in the financial habits of the people. This would reduce the risk of carrying cash, reduce corruption, attract more 
investors to the economy through new modes of investments, reduction in cost of banking service, technological and financial literacy and so forth (Shendge et al., 2017). Cashless economy provides adequate mechanism for higher tax collection as observed in Europe where a negative relationship between cashless transaction and size of shadow economy is also comprehended (Kearney \& Schneider, 2013). This was also confirmed in the study of 26 European Union countries with regard to VAT (Value Added Tax) (Madzharova, 2014).

The idea of a cashless economy was already in picture since the last decade or so. It got a major push with the demonetisation of the ` 500 and 1000 notes on November 8, 2016. It was a prominent growth driver for bringing out digitisation in the country (Kumar, 2017). The economic survey (2016-17) of India points out that higher the cash in circulation higher is the corruption on the line of report provided by Transparency International. This served as a major argument for the demonetisation move. However, looking at the currency to GDP ratio of other countries gives a different view on the topic. In last few years Japan, stands higher in terms of currency circulation than India, yet they rank much better in terms of corruption indicating a divergence in the argument. Similarly, Brazil has a very low currency to GDP ratio in comparison to India and has moved away from cash based transactions yet they rank is very high in terms of corruption. This shows that mere corruptive practices and cashless economy or demonetisation cannot be linked to a transparent economy as other factors might also affect the process of a corrupt free economy (Easy Money, 2017).

The literature review presents the benefits and challenges of a cashless economy from numerous angles. The recent demonetisation has pushed the Indian economy towards a series of digitisation process which is directly related to cashless based transactions. The present study is focused on bringing out the benefits, operational viability, weakness and challenges of cashless transition in the Indian economy. The area is dynamic in nature with numerous changes taking place every day. This provides a suitable research gap to explore the present scenario and fill the literature vacuum. Further it will also help to formulate a scope of further research on the issue.

\subsection{SWOC Analysis}

\subsubsection{Strengths}

\section{a. Reduction in Cost, Time and Effort}

Cashless society signifies payment through paperless currency in the form of electronic means. This reduces the operating cost, time and effort of the payment channels. As mentioned earlier the annual cost of maintaining transactions in the form of paper currency is humongous. It ranges from printing, circulating and distributing the banknotes throughout the country across different channels such as Banks and ATMs. India is a country with scattered banking network and an efficient circulation of currency brings huge costs, time and effort for the RBI and Banks. A rough estimate shows that around 35,000 men and 8,800 vehicles are used to maintain more than 2,00,000 ATMs where the cost of maintenance is ` 10,000 crores. These costs are borne by the customers as the banks do not have other means to cover them (Sharma, 2017). Cashless initiative would reduce the cost of ATM. The time and effort taken for over-the-counter (OTC) transactions will also be reduced. Moreover, the staff engaged in the OTC can be used for other productive means.

\section{b. Adequate transparency in economic activities}

One of the major issues in Indian economy is the lack of transparency and accountability in the financial transactions which affects the revenue collection of the Government. This has boosted the growth of shadow and parallel economy which has further increased the amount of black money. Although the exact amount of black money is difficult to estimate, however, it has been alleged to be enormous in India and is regarded one of the major setback for development. As per a study India's black money is expected between 23 percent to 26 percent (Schneider, 2006). A newspaper article by The Hindu reported that black money accounted to 75 percent of the GDP (Mehra, 2016). Thus, going cashless would bring more transparency and accountability. Additionally, it would also reduce frauds, corruptive practices, hawala transactions and scams as there would be digital trail for every transaction enabling checks.

Along with this, the tax revenue is also expected to go up. India suffers from a lower tax revenue in comparison to world average. The world average stands at 20.2 percent whereas India is at 17.7 percent. The lower tax is because of complicated tax structure and lower compliance. However, Goods and Service Tax (GST) is expected to sweep in positive changes and India is expected to catch up. The GST is completely based on digital platform which makes it difficult to avoid. All the transactions would leave digital footprints which would enable the authorities to check. 


\section{c. Changing patterns in terms of Internet and Smart Phone usage}

The transformation to a cashless economy is highly dependent on the fact that India has progressed in a digital wave by becoming one of the largest market of smartphones just after China which is at the top. According to Telecom Regulatory Authority of India (TRAI) mobile subscribers have increased to 1,204.98 million by the end of May 2017, showing a tremendous growth. Certain service providers like Jio, Airtel, Vodafone and so forth have come up with numerous attractive cheap plans of Internet that has been adding new customers with every second. This has attracted local as well international mobile manufacturers to introduce mobile handsets at range of prices from both low end to high end. This has also provided a scope for the emergence of non-banking payment platform known as mobile wallets or e wallets such as Paytm, Mobikwik, Chillr and many more.

\section{d. Evolution of Banking}

Apart from non-baking channels the banking channels in India has undergone a huge change since independence. The services in Banking industry has developed to a great extent in bringing out efficient delivery mechanism for the general public. Non-Cash payments such as Debit Card, Credit Card, RTGS (Real Time Gross Settlement), NEFT (National Electronic Funds Transfer), DD (Demand Draft), Internet Banking, Mobile Banking, App based banking etc. has brought tremendous boost to the cashless movement of India.

\section{e. Socio-Economic and Financial Development}

A large part of Indian population is abstained from availing banking services despite various initiatives by the Government. Although the Prime Ministers Jan Dhan account initiative has garnered quite a number of accounts however, in terms of Banking services many are left out and many have zero balance accounts without any activity in them (Livemint, 2017). Studies have shown that accounts opened under these schemes does not have any activity (Gangopadhyay, 2009). Since mobile banking serves a major scope for going cashless, connecting these accounts with the users would enable them for digital transactions. This would bring more activity as well in the accounts and empower the poor with efficient way of handling finances.

\section{f. Effective disbursal of Schemes}

Another major setback in effective disbursal of development schemes is bureaucracy and leakages in the agencies of the Government. For instance, due to this the low-income groups are not benefitted in time which affects the economic development. The use of computerised methods would allow the Government to keep track of timely payments being made to these beneficiaries. Numerous schemes can be linked that would allow the Government for efficient disbursal of monetary benefits without any bureaucratic loopholes which were prevalent earlier ensuring transparency, security and efficiency. Direct Benefit Transfer (DBT) is one best example of this.

\section{g. Miscellaneous}

Going cashless would also bring other benefits that would impact the life of each and every individual in a positive way. One of such is impact on natural resources such as paper, fuel, electricity and so forth. A cash intensive economy requires and consumes more power in comparison to a cashless economy. The risk of carrying cash would also reduce theft and robbery. The digital platforms can be accessed anytime allowing flexibility of operations. The problems of fake currency can also be avoided in cashless economy. Since there are always digital footprints in computerised transactions, sponsorship of unscrupulous like terrorism etc. can be checked and avoided by the authorities with ease.

\subsubsection{Weakness}

\section{a. Infrastructure Issues}

India has been suffering from lack of adequate infrastructure since ages. There are many parts of the country where electricity, roads, telecommunications, water, proper houses, schools, health care facilities and so forth are major issues yet to be solved. In this scenario a thorough, cashless economy cannot be expected without proper solution to these problems. The IAMAI (Internet and Mobile Association of India) estimates only that only 35 percent Indians have access to internet as on Dec 2016. Along with this poverty is another issue that affects its positive development as poor people cannot purchase smartphones, computers etc. which are essential for digitisation. Infrastructural loopholes also held back access to conventional banking in these parts of the country. Since digitisation process requires access to electricity and telecommunications it is imperative in the present context.

\section{b. Digital Illiteracy}

Over the years India's literacy rate has risen from 12 percent during the British era to 74 percent as per the census of 2011. The world average is at 84 percent leaving a room of improvement. This makes it difficult 
for introduction of mobile and internet banking platforms. The changing face of internet service industry and use of smartphones in India recently is expected to bring in significant development. The digital literacy in India is far behind as most of the masses are adamant to the use of digital platforms due to habitual convenience towards the use of physical transactions. Moreover, India has a shortage of skilled workforce with only 2.3 percent having any formal basic training which is far behind the world average of 50 percent (Prayank, 2017). A joint study by ASSOCHAM-Deloitte estimates that around 950 million Indians are out of Internet. Thus, the need of digital literacy along with formal literacy cannot be denied as a major share of the population has no idea of the processes involved in cashless transactions.

\section{c. Larger Share of Rural Population}

A recent report estimates that in 2017 about 72.2 percent of the Indian population lives in approximately 638,000 villages (Indiaonlinepages, 2017). The rural sector suffers from various glitches of development such as lack of basic infrastructure, amenities etc. They also suffer from illiteracy due to lack of proper educational institutions. Further, due to this the penetration of internet services and smartphones at this moment is low. This creates a setback for the Government in introducing cashless means replacing cash intensive transactions. However, the scope of development is promising in coming years with the effort of the Government towards developing these aspects.

\section{d. Lack of confidence}

This has direct link with the digital illiteracy of the Indians due to which they lack confidence in using digital platforms. Every now and then security threats surface up in the form of scams and frauds in the digital world due to unscrupulous means which further contributes to this scenario. Another issue is the lack of thorough implementation of security policies by the Government and their agencies towards cyber frauds. There are laws and acts to it, however, efficient execution is lagging behind as financial frauds through digital platforms are increasing at a fast pace. The lack of awareness by individuals about various information related to digitisation also affects to it.

\section{e. Largely Unorganised}

Indian economy is largely unorganised due to various shortcomings that are sediments of political, geographical, demographical, cultural conventions. This has a deep influence in the workings of the various markets throughout the country. Numerous, aspects of the economy are not controlled or regulated by the Government which leaves a room for inefficient application of the digital schemes. This serves as a weakness for a cashless economy.

\section{f. Miscellaneous}

There are other miscellaneous facts too that affects the implementation of cashless economy. It has been alleged not to be effective in curbing black money. This is because most of the black money is absorbed in holding assets. Further, sudden implementation of demonetisation has created a shockwave among the citizens without any back up plan. This has jeopardised the lives of the common people more who are engaged in low value transactions than the rich people. This loss is irreversible in nature for many people particularly cash dependent sections of the society. There is also a setback in terms of privacy of the citizens.

\subsubsection{Opportunities}

\section{a. Better Execution of Social Schemes}

The digitisation process and cashless system will increase transparency and accountability of monetary transactions across various departments of the Government. This would allow the bureaucratic loopholes to be fixed which earlier had various troubles in coordination. A common person had to move from office to office for bringing in terms of his or her social security schemes. A setback to this in cashless system might be the digital literacy factor, however, in coming years it would bring more smoothness and efficiency to the implementation and execution of various social schemes under the Government. Another important observation is the ghost beneficiaries in many schemes which are not be verified due to shortage of resources by the respected agencies. These benefits are taken by corrupt officials and higher statute persons of the society through a nexus. Going cashless would help in curbing these activities and bring fairness to the needy and the poor.

\section{b. Improvement in Skill and Knowledge}

Cashless society would compel the citizens to know the use of various digital platforms as they are interlinked. This will bring new knowledge and development of skills among the people. One of basic advantages of internet and digitisation is sharing of knowledge globally which brings different people to one platform. Further, this will also increase digital literacy. 


\section{c. Better Revenue Generation}

Cashless systems leave room for better implementation of tax policies. Earlier in cash intensive mediums the Government had no full records of the transactions that took place in the economy. Cashless systems leave digital footprints, which enables the authorities to curb tax evasion and also enforce appropriate taxation. This will also help efficient monitoring for fixing better convenient tax rates on the various sectors of the economy.

\section{d. Efficient Use of Resources}

Digitisation brings efficiency to the various processes in the economy. It is expected to save time, effort and money as automated systems will take over and bring swiftness in the economic activities. Manual systems need time and always has a setback of maintaining uniform quality in providing services. Digital methods provide a uniform standard and maintains quality consistently for the services. This creates efficiency among the staff too who are engaged through digitisation processes.

\section{e. Economic Growth}

Studies have shown that increase use of cashless means have contributed positively in the economic development of the nation. This has been discussed in the literature review with suitable evidence (Moody's Analytics, 2013; Zandi et al., 2013; Hasan et al., 2013, Kapoor, 2016). The digitisation channels will ensure maximum transparency, efficiency and effective means of economic transactions saving time and effort. This will possibly reflect to better economic growth and development.

\subsubsection{Challenges}

\section{a. Digital Safety and Security}

One of the major challenges in India is safety and security not only in the domain of physical life but also in digital world. One of the major problems in digital systems are that data are stored in huge quantities which makes them more vulnerable without proper cyber security. A breach swipes away sensitive information at one go unlike physical frauds where consumers get affected individually where there is a chance for snapping the fraudsters. An example with this regard is the news of 3.2 million cards affected in October, 2016 with data leakage which included cards from Visa, MasterCard, RuPay etc. A recent virus also affected the debit cards in 2017, where millions of cards were blocked causing trouble for the consumers. Another example is the Ransomware programs that has become a pandemic for security lock ins. The use of digital payments also increases risks with increasing threats of cyber-attacks and data leakage. Proper grievance redressal process should also be established for a hassle free transition. Thus, using digital means for payments are really time saving and efficient but a security breach makes it a nightmare for the common people whose hard-earned money exposed to these risks.

\section{b. Privacy Issues}

Going cashless leaves, a digital trail of the transactions, which although beneficial for the Government for curbing black money and collect tax, however, violates a fundamental right of privacy and choice by the citizens. The information if misused will destroy lives of the person. Every now and then the breach of security of aadhar cards has caused a worry for the common people as well as the Government. Aadhar has been pushed by the Government as a base in all the aspects of the economy. However, the security issues have discouraged the general public towards other digital means. There is a possibility of misusing the information and cause identity theft for the common people leaving them helpless.

\section{c. Vulnerable Sections of the Society}

Certain sections of the society such as the poor, women in general and so forth suffer from scarcity of resources for sustenance of normal life. With this regard the forcing attitude of the Government will bring more chaos to the lives of the common people. Instead of imposing the digital movement the policy makers should try to improve the basic infrastructure and the overall lives in various dimensions. As mentioned earlier, lack of public utilities such as roads, telecommunications, schools, hospitals have drastic effects on the lives of the people physically as well as mentally. This remains to be a significant challenge for developing India as a superpower as there are major traces of poverty and impoverishment due to lack of infrastructure.

\section{d. Curbing Black Money}

The authorities claim that introduction of cashless systems would help to curb black money and corruption to a large extent. This seems to be convincing in theory, however, in reality the loopholes and setbacks in the systems leave enough room for discrepancies. The black money problem not only relates to holding of cash, but also refers to the holding of assets in India and other offshore places. There are various 
means by which the rich and the powerful bend the laws for their advantage with this regard. This jeopardises the lives of the poor as they are being harassed instead with stringent laws. The challenge remains open for the Government to fill these gaps (an example of this is the Benami Transactions (Prohibition) Amended Act, 2016). It would be interesting to see how the authorities erase the problem of corruption in future.

\section{e. Role of Government}

The Government should not impose the use of cashless systems as India suffers from various shortfalls in terms of digitisation. On the contrary the Government should encourage its use methodically keeping in mind of the digital illiteracy of the country. A suitable mean to it is organising awareness campaigns, interactions at various levels from schools, colleges, universities, offices and so forth. This will help in building the confidence of the common people in using digital means. The Government should not be forceful ( an example of this is the demarcation of cash transaction limit of 2 lacs and other transactional limits in Banks) and be supportive in bringing this development as this would be an efficient transition for a huge cash intensive nation like India.

\section{f. Connectivity Issues}

A major challenge in digitisation process is the network. India is a vast nation which is scattered and bringing it under one roof of telecommunication is a huge task. The improvement in recent years to this is promising. However due to increasing use of internet the network suffers overload. Some of the places even with electricity are not availing the internet services due to lack of other resources. Thus, to push digital movement, improvement of network and network based infrastructure is a necessity which should be taken care of swiftly.

\subsection{Conclusion}

The present business space has evolved magnificently over the years and has continued to revolutionize trade and commerce globally. The history of civilisation shows how the need of exchanging goods and services gave birth to barter system which formed a baseline to the development of money as a medium of exchange. Coins were minted in precious metals in medieval times, followed by more coins, banknotes and monetary instruments in modern age. This developed a habit among each and every individual to plan their life on the basis of its availability. However, the advent of technology especially IT (Information Technology) has brought forward an efficient and effective processes in the form of digital payment systems. Since, its introduction in the early 1990s it has grown as a major platform for exchanging services and goods.

India is an unparalleled country with a vast depth to its culture, economy, geography and so forth. Since the ages it has been hugely cash intensive. Introducing cashless systems is a bold move by the authorities since we have various major shortcomings (like poverty, etc.) which hinders an all-round development. The analysis indicates that transformation to a cashless society would provide faster and economical way for the common man to make any economic transaction. This would impact to a positive growth of the economy including the use of less resources. Further, this would increase transparency, monitoring for the Government and confidence of the public. However, at the same time there are various vulnerabilities to it that needs to be addressed. First and foremost, setbacks such as the lack of outreach in electronic payment modes, infrastructural issues, digital illiteracy, cyber security and the lack of privacy are deep rooted which needs to be solved at a rudimentary level.

To implement a smooth transition from cash intensive to cashless society the Government needs provide appropriate incentives which will encourage the common people for opting the services. Moreover, small vendors should also be taken into consideration with an effort for providing PoS (Point of Sale) terminals, E-Wallets, Portable ATMs at an affordable rate. The Government departments should also make it compulsory for the use of digitisation process in their works. Alongside these, grievance redressal and customer service are another aspect which should be done diligently to maintain the confidence of the people. Largely, the authorities should try to remove the digital divide across the country which will ensure the prosperity of the nation in terms going cashless. 


\section{References}

[1] Chakravorti, B., \& Mazzotta, B. D (2013). The cost of cash in the United States. Institute for Business in the Global Context, The Fletcher School, Tufts University.

[2] Easy Money (2017). Economic Survey's Spin on Demonetisation Doesn't Quite Add Up. Retrieved October 26, 2017, from https://teekhapan.wordpress.com/tag/currency-to-gdp-ratio/

[3] Gangopadhyay. S (2009). How can Technology Facilitate Financial Inclusion in India? A Discussion Paper. Rev MarkIntegr 1(2):223 - 256

[4] Hasan. I., De Renzis. T., \& Schmiedel, H. (2013). Retail Payments and the Real Economy. ECB WorkingPaperSeries,(1572).https://www.ecb.europa.eu/pub/pdf/scpwps/ecbwp1572.pdf?0568b27871896eb01f54b 0c4c40a8f63

[5] Indiaonlinepages.com (2017). Population of India. Retrieved on Oct 20, 2017 2017http://www.indiaonlinepages.com/population/india-current-population.html

[6] Kearney. A.T., \& Friedrich Schneider, F. (2013).The shadow economy in Europe, 2013. https://www.atkearney.com/documents/10192/1743816/The+Shadow+Economy+in+Europe+2013.pdf

[7] Kruger. M., \& Seiz, F. (2014). Costs and Benefits of Cash and Cashless Instruments. https://www.bundesbank.de/Redaktion/EN/Downloads/Publications/Studies/costs_and_benefits_of_cash_2014.pdf ?__blob=publicationFile

[8] Kumar, N (2017). India's Move towards Cashless Economy-Options and Status. Pacific Business Review International, Volume 9 Issue 12, June 2017

[9] Livemint (2017). 19\% of India's population still unbanked: Assocham-EY report. Retrieved on 23 Oct, 2017 from http://www.livemint.com/Industry/E8BrA0gzu5iHo3uC1XjvbK/19-of-Indias-population-still-unbankedAssochamEY-report.html

[10] Mazzotta, B., Chakravorti, B., Bijapurkar, R., Shukla, R., Ramesha, K., Bapat, D., \& Durgavanshi, S. (2014). The cost of cash in India. Institute For Business in the Global Context.

[11] Mehra, P (2016). Black economy now amounts to 75\% of GDP. Retrieved on Oct 26, 2017 from http://www.thehindu.com/news/national/black-economy-now-amounts-to-75-of-gdp/article6278286.ece

[12] Moody's Analytics (2013). The Impact of Electronic Payments on Economic Growth. https://usa.visa.com/dam/VCOM/ download/corporate/media/moodys-economy-white-paper-feb-2013.pdf

[13] Prayank (2017). 950 Million Indians Are Facing Digital. Guiding Tech https://www.guidingtech.com/63245/950million-indians-digital-illiteracy/

[14] Schneider, F (2006) " Shadow Economies and Corruption All Over the World: What do we Really Know? " http://ftp.iza.org/dp2315.pdf

[15] Sharma, S (2017). Banks can Bank on IoT for Higher Efficiency. Retrieved on October 26, 2017, from https://www.credencys.com/blog/banks-can-bank-on-iot-for-higher-efficiency/

[16] Shendge, P. A., Shelar, B. G., \& Kapase, S. S (2017). Impact and Importance of Cashless Transaction in India. International Journal of Current Trends in Engineering \& Research (IJCTER), 3(4), 22-28.

[17] Zandi M., Singh V., \& Irving, J. (2013). The Impact of Electronic Payments on Eonomic Growth. https://usa.visa.com/dam/VCOM/download/corporate/media/moodys-economy-white-paper-feb-2013.pdf 